\title{
Reading Difficulties in Narrative Text through "Edmodo" at Vocational High School
}

\author{
Suyadi
}

\begin{abstract}
Faculty of Teacher Training and Educational Sciences, Universitas Batanghari Jambi-Indonesia Corresponding author.Email: suyadi@unbari.ac.id
\end{abstract}

\begin{abstract}
Interpreting information of a language through the medium of printing refers to reading as a process of receiving massages. This study is aimed at analyzing Edmodo application of learning narrative text at vocational high school with an interview as data collection technique. Using Edmodo application is more complicated while it was mixed with generic structure, language feature, finding main idea, and students' vocabularies are limited. Some teachers were also faced difficulties while applying Edmodo application in the classroom but they argued it was a better one used where teachers and students could make discussion through this application. Teachers need special training for better using of Edmodo application.
\end{abstract}

\section{Keywords: Edmodo, Difficulty, Narrative text, Online Learning}

\section{INTRODUCTION}

Reading plays important role in learning a language, achieving academic improvement, and reaching career promotion [1]. Reading could construct mindset and boosting students' vocabulary, and grammar knowledge. Reading is not merely hearing words [2], but also understanding added dimensions of it, paying more attention of text, analyzing of massages, and acting of possibly basis of text. While, [3] adds academic success and achievement can be reached through reading which means that the better reading skill the students can reach, it would be the better learning achievement they obtained. Reading has an important role to improve students' language skills while it is taught combining with another skill. [4] stated that there is a correlation among four language skills and through reading learners may develop reading skill.

To master reading skill needs more efforts especially in the era of Covid-19 Pandemic teaching and learning paradigm which is emphasized online-learning as Covid-19 Pandemic impacts to the educational institutions. As of 6 May 2020, Covid-19 spread all over the world which is also impacted to teaching and learning process, Indonesian government through Ministry of National Education's instructs to use online learning such as Edmodo, Google Classroom, Whatsapp Group, Zoom Meeting, and the like to keep the educational process runs. This research was conducted at Vocational High School in Jambi City which focuses on Edmodo online teaching media with reading narrative text as the main material. [5] Habibi et al
(2021) stated teachers should have a positive perception on technology integration in teaching and learning English specifically using Edmodo as a platform of instruction widely used by English teachers and lecturers as well [6].

\section{LITERATURE REVIEW}

Edmodo as a Teaching and Learning Media Edmodo is a global education network that could help to connect learners to people, resources, teachers, and lecturers all over the world. Edmodo teaching media brings everyone in educational community at the same time helping students to get better success in learning. Through Edmodo teachers or lecturers can create better content and platform of learning materials to students and also can help students to discover passions in learning by sharing ideas, problems, and helpful tips.

Nicolas Borg and Jeff O'Hara built Edmodo application in 2008 with its advantages: 1) provides students to give questions by writing on the walls which they do not have chances in conventional classroom, 2) Teachers and students can make discussion through the walls of Edmodo, 3) Teachers share assignments, 4) students use computer or laptop in more skillful, 5) Learning materials can be uploaded in form of videos/ppt for presentation, and 6) Online private community to encourage communication and collaboration in learning is more effective between students-students, or teachers-students.

Various current uses of Edmodo application in classroom are aimed at improving reading skills, assignments, and paper-studying, including creating a 
post for assignment and quiz, polls for student's response, embedding learning-video clips, creating groups, and a calendar events. Edmodo stimulates teaching and learning process through kinds of interaction such as contents, information, and assignments, including posting topic for discussion. The weakness of using Edmodo application is the video conference is still unavailable which is the important part to interact with students to give the more or detail explanation about the materials. In addition, Edmodo's language is English, so that some students still unfamiliar with the features and instructions in application which could not change the language to Indonesia. However, it can be used in high school [7] in English language learning.

In line with the use language in Edmodo application is English, it is relevant with teaching and learning at vocational high school, specifically in reading narrative text. As stated by [8] reading is interpreting information of a language through the medium of printing as a process of receiving massages, or reading an online media is to create encoding model process. Top-down models of cognitive reading and language competence of readers' are played key role in constructing meaning. Interactive model is specifically for skilled or advanced reader in reading simultaneously. These models are based on the reader background which are suitable or position their skills of the reading.

Not only models of reading. But reading also has some technique, in general aspect reading skill has main techniques, they are skimming and scanning technique. [9] states that skimming technique is to look for massages in a quick idea to assume specific information in a text only. While, [10] gave more intention on two strategies are equally help students to read more focused and efficient. Skimming and scanning are accelerated strategies to look for specific information with a specific speed in reading. [9] said that skimming and scanning strategies are desirable reading skills to get information easily in efficient way. Those are some the theories of reading that all of the teacher and learning should know, also the reader to get the text information easily and faster.

\section{TEACHING READING}

Teaching reading has some steps which may help students easy to get information, such as background knowledge, strong vocabularies-based, verified prediction, increasing reading rate, reading strategy, building assessment and evaluation, and striving for continuous improvement [11]. Quantitative assessment includes information from reading comprehension tests as well as reading rate data including journal responses, interest surveys, and responding of strategies checklist. Reading teacher should strive continuous improvement and actively teach students what to do and understand nature of reading process, and put themselves as facilitators to help reader to discover best massages.

\subsection{Teaching Narrative}

Teaching narrative is to amuse with actual or vicarious experience using various ways to tell, entertain, and inform massages to readers, and listeners [2], [13]. [12] gave more intention on most powerful ways of communicating is using narrative which tells an event, find an engaging in thinking, detail and clear in arranging the order in effective way.

\subsection{Generic Structure}

There are five kinds of narrative generic structure proposed by [13] and [13]. 1) Orientation introduces main characters and possibly minor characters and indicates where action is located and when it is taking place. 2) Compilation pushes a serious of events from rising to problem to arise where unexpected action happen involving main characters in the story. 3) Sequence or climax tells how characters react to compilation including their feeling and what they do in the story. 4) Resolution resolves for a better or a worse situation, it is left unresolved in the story to create readers' eagerness. 5) Re orientation acts as optional closure of event in the story.

Readers should know narrative generic structure text to help readers find plot and information in the text. Not only that, but also could help the reader could feel what the narrator tells. For Instance, the character is which have many types of antagonist and protagonist.

Features

As suggested by [13] narrative has four features: 1) Nouns identifies specific characters and places, 2) Adjectives provides an accurate description of the characters and settings in story, 3) Verb shows actions in the story, and Time tells about specific time of story happens. Language features also the crucial sign in English text which have many kinds of text. To know language features of text, helping readers to guess the meaning of words.

\section{METHOD}

This research was conducted during the spread of corona virus at one of State Vocational High School academic year 2020/2021. The findings of the research could be taken as beneficial results for people who responsible to anticipate future pandemics challenges. Design of this research is descriptive qualitative [15] by investigating difficulties faced by students when learning reading narrative text through Edmodo online application.

Exploring case study as a system, researcher limits a clear account regarding investigation to emphasize a holistic approach in order to create a mutual correlation between phenomena, context, empirical, empirical, and integrated design. In achieving the aim of the research, researcher set a research question: what kinds of difficulties were faced by students when learning reading of narrative text through Edmodo online learning?

\subsection{Procedures and Participants}

An important thing in conducting a case study research is gaining access into participants to collect 
qualitative data. This research was conducted at one of State Vocational High School during Covid-19 pandemic, where teaching and learning process are conducted from home. This dramatic change to both students and teachers due to technological adaptation is not easy to adapt. A purposeful "convenient sampling was implemented to get data, as what [14] (p.126) said that it represents sites or individuals cases make researcher easy to access data". Sampling strategy was implemented to choose site and participants of study [14], and to obtain access through communication with principal of the school.

\subsection{Instrument of the research}

Researcher exploited 6 questions of interviews to get the data which was related to the text of The Malind Kundang and used of Edmodo application. Due to the Covid-19 pandemic is still happening, so the interview was conducted through video calls application to reveal difficulties faced by students while learning Narrative Text through Edmodo. The students were given a text of The Legend of Malin Kundang and asked them to read carefully. First paragraph tells about orientation that introduces main character of story. Second, compilation that pushes a raising events effect to unexpected happens to main character. Third, sequence or climax that tells about action taken by main character to anticipate action happened before. The fourth is resolution that tells about resolving of happenings whether it is better or worse taken by main character. In re-orientation tells about optional closure of Malin Kundang's story.

After giving students text to read, the researcher asked them to read in order to get deeper understanding of text, and interviewed related to generic structure and language feature, difficulties in learning narrative text, learning using Edmodo application, reading comprehension, Edmodo as a learning application, and learning English using Edmodo.

The researcher used structured interview technique to collect the data using 6 certain questions to all students through video calls application. Video calls interview lasted from 5 to 10 minutes, students were asked to explore their thoughts related to Malin Kundang, a narrative text and Edmodo as media of learning. To make a verification and accuracy of interpretation, member checking was implemented by giving back transcript to participants to ensure their agreement with reported quotations [14];[5].

\section{RESULTS}

Findings of this research revealed three main difficulties following results they are technological difficulties, lack of knowledge in narrative text, lack of motivation in learning English. The researcher determined findings based on the online interview with 6 the students that were done in February 1th, 2021. The researcher recorded the online interviews answered as follows:

Relates to generic structure the students were responded that it was not easy to find out the generic of narrative text while using Edmodo application due to limited time available. While another student did not give answers which may be concluded that they were not interested learning using Edmodo.

Related to difficulties learning narrative text using Edmodo application students gave responses that students were not interesting learning English as it is not used in daily conversation and unfamiliar vocabularies. Related to the process of learning English using Edmodo application students gave response that it lacks of explanation which impacted to a banal understanding of materials. In general students gave answers related to Edmodo application were excellent as they could share pictures, giving direct answer and comment as well and it is more effective application for learning English.

There are two categories related to difficulties of using Edmodo application in learning English, named lack of vocabulary, and using the application itself.

The problem of students in learning English using the Edmodo application, ie. Edmodo does not provide video delivery make the students cannot send videos through Edmodo application. On the other hand, the teacher cannot send video materials which can make students get further explanations about the text. Another thing is, the Edmodo application does not have notifications when the teacher sends material or assignments due to students being late or failing to submit assignments. This is one of the main problems in the Edmodo application. In addition, the language of instruction used in the Edmodo application is English, some students do not know how to operate the Edmodo application even in English lessons. Finally, opening the Edmodo application, students must have a strong internet signal and data, most of which have limited signal and data.

As one of the difficulties is technological knowledge, some English teachers at vocational high school in Jambi City argued that they need a special training on using internet teaching application. One of them informed:

\section{"It is hard for me to apply internet application for teaching, more specifically using Edmodo. I need a special course for it",}

Teachers' difficulties in using online application may results to the students' understanding in teaching materials. Teachers have limited knowledge regarding technology integration need to have training on it. Students do not have smartphones or other devices to support their educational activities [5] make online learning through Edmodo does not run well.

However, these findings have informed teacher about problem that must be anticipated during using Edmodo as application in learning activities. This material adopt material from [16]. The used of Edmodo is promoted in the previous studies [7] as one of learning media, however it also has some potential problems in the implementation. 


\section{CONCLUSION}

There are two categories of difficulties; first is based on the difficulties in reading Malin Kundang text, such as limited vocabularies causes knowing not text. Then, the next problem is related to students' problem in using Edmodo application. Teachers' difficulties in using online application may affect students' understanding. Teachers have limited knowledge regarding technology integration need to have training on it. Besides, students problem is related to their the devices to support their educational activities.

\section{REFERENCES}

[1] Sugirin et al. (2019). Fostering Students' Reading Comprehension Ability through Directed Reading Thinking Activities (DRTA) Strategy. Journal of English Language Teaching and Linguistics. Yayasan Visi Intan Permata (Centrall)

[2] Amer, Aly, (1992). The Effect of Stord The Grammar instruction on EFL Students Comprehension of Narrative Text.

[3] Odwan, Hameed. (2012). The Effect of the Directed Reading Thinking Activity through Cooperative Learning on Secondary Stage Students' Reading Comprehension in Jordan. International Journal of Humanities and Social Science, Vol 2(16), 138151. Cohen, Louis, Lawrence Manion., \& Keith Morrison. (2000). Research Method

[4] Nunan, D. (1991). Language Teaching Methodology. London: Prentice Hall.

[5] Habibi, et al. (2021). Mapping Instructional Barriers during Covid-19

[6] Mokhtar \& Dzakiria, (2015). Illuminating the Potential of Edmodo as an Interactive Virtual Learning Platform for English Language Learning and Teaching. Malaysian Journal of Distance Education 17(1), 83-98 (2015)

[7] Monalisa, M., \& Ardi, H. (2013). Using "edmodo" educational social network in teaching English for high school students. Journal of English Language Teaching, 2(1), 220-225.

[8] Suyadi. (2021). Suggestopedia Method Effect on Reading Descriptive Text at a Senior High School. Jurnal Ilmiah Universitas Batanghari Jambi (Vol.21, Issue 2: p. 485-496). Retrieved: http://ji.unbari.ac.id/index.php/ilmiah/article/viewF ile/1483/861

[9] Ngabut, M. N. (2015). Reading Theories and ReadingComprehension.Journal on English as a Foreign Language, 6.

[10] Harmer, J. (2001). The Practice of English Language Teaching. Harlow: Pearson Education

[11] Brown, (2001). Teaching by Principles: and Interactive Approach to Language Pedagogy. New York: A Pearson Education Company.

[12] Carrel. (2021). Retrieved 9 2, 2021, from indeed career guide: https://www.indeed.com/careeradvice/career-development/how-to-improvereading-skills
[13] Momeni, J. (2016). Narative Theory: A Shift Towards Readers Response. Research Gate , 5.

[14] Anderson, T. (2000). Teaching in An Online Learning Context. Athabasca University.

[15] Creswell, J. W. (2014). Research Design. United Kingdom: SAGE Publication.

[16] Utami, Z. R. (2016). Bahasa Inggris Kelas X SMA/SMK/MAK/MA. Jakarta: Katalog Dalam Terbitan. 